\title{
7 \\ OFFENSIVE AIR OPERATIONS OVER KOREA The first challenge for Australian naval aviation
}

\author{
Jack McAffrie
}

The Royal Australian Navy's Fleet Air Arm was formally established on 28 August 1948 with the commissioning of the 20th Carrier Air Group at Royal Naval Air Station Eglinton in Northern Ireland. ${ }^{1}$ A little over three years later, the Fleet Air Arm was at war, with HMAS Sydney (III) and her Carrier Air Group deployed off the coast of the Korean Peninsula.

By any measure, the establishment of the Fleet Air Arm, and its rapid progress to being a highly efficient and effective operational entity, is a remarkable story. There were political, bureaucratic, financial, manpower and timing challenges, any one of which might have brought the process to a halt, especially in the early stages. That Sydney and her air group deployed to Korea and performed so well was the result of determination on the part of the RAN leadership, enlightened political decision-making, and a mix of experience and youthful enthusiasm among all concerned.

1 A version of this paper was first published in Sea Power Ashore and in the Air, ed. D. Stevens and J. Reeve, Halstead Press, Sydney, 2007. 
Reflecting on the performance of the Fleet Air Arm in Korea-and indeed of the destroyers and frigates, which also distinguished themselves-the RAN would have had every reason to look to the future with confidence. Yet a mere seven and a half years after Sydney returned from Korea, and only 11 years after the establishment of the Fleet Air Arm, its demise was announced by the government in November 1959, scheduled for 1963. Clearly, operational excellence was not sufficient on its own to ensure organisational survival.

\section{Formation and workup}

Early planning anticipated that the first carrier would be commissioned in June 1948, and the second would follow in 1949 or $1950 .{ }^{2}$ The RAN also expected that the Royal Navy (RN) would provide the majority of the aviation and air group personnel at first. The RAN also began its own training programs. No. 1 Naval Air Pilots Course began in HMAS Cerberus on 7 December 1947, and nine of the 14 starters graduated at RAAF Base, Point Cook, on 29 July 1949. They then undertook operational conversions in the UK on both Fireflys and Sea Furys, completing in April $1950 .^{3}$

The second pilots' course began in August 1948; the RN also loaned a number of observers and telegrapher air gunners to the RAN. The first group of ex-naval (RN, RAN Volunteer Reserve and Royal New Zealand Navy) and ex-RAAF aircrew joined HMAS Cerberus on 6 February 1948 for a six-month orientation course. They then travelled to the United Kingdom for further flying experience and to join either the 20th or 21st Carrier Air Group. ${ }^{4}$

The Fleet Air Arm was established on 28 August 1948, and four months later HMAS Sydney was commissioned in Devonport, England, with Captain Roy Dowling as commanding officer. Air Group workup in the UK entailed the full run of proficiency and operational flying, including deck landing practice in RN Fireflys and Sea Furies. Lieutenant

2 A. Wright, Australian Carrier Decisions: The Acquisition of HMA Ships Albatross, Sydney and Melbourne, Papers in Australian Maritime Affairs, No. 4, pp. 151, 157, www.navy.gov.au/sites/default/ files/documents/PIAMA04.pdf.

3 Australian Naval Aviation Museum friends and volunteers, Flying Stations: A Story of Australian Naval Aviation, Allen \& Unwin, Sydney, 1998, p. 53.

4 Ibid., p. 54. 
Danny Buchanan caused some excitement on 17 March 1949 while landing on HMS Illustrious. His Firefly missed the wires, jumped the barrier, destroyed four other Fireflys in the forward deck park and was itself also destroyed. ${ }^{5}$ Nevertheless, no one on deck was hurt, and as he himself walked away without a scratch, the landing must be recorded as a good one.

Eventually, the 20th Carrier Air Group and HMAS Sydney sailed for Australia on 12 April 1949 and arrived in Jervis Bay on 25 May. Flying for the air group began from the newly commissioned Nowra Naval Air Station in June, and there were two embarked periods between then and April 1950. ${ }^{6}$ Sydney then returned to the UK to bring home the 21st Carrier Air Group, arriving in Australia in December 1950. This transport task meant that the ship and the air group were unavailable to reinforce the Commonwealth effort in the Korean War, which had broken out mid-year. ${ }^{7}$ There had been some consideration of replacing HMS Theseus with Sydney, and there was an expectation that the issue might be raised again. ${ }^{8}$

Indeed, by March 1951 the Chief of the Naval Staff, Vice Admiral Sir John Collins, had received a request from the First Sea Lord for Sydney to replace HMS Glory in Korea in late 1951. Consequently, in May 1951 the navy decided to form an air group from Nos 805 and 808 Sea Fury Squadrons and No. 817 Firefly Squadron, and workup plans began immediately. Most air group members were RN personnel, but most of Sydney's ship's company were Australian. The workup was costly in aircraft, with weather contributing to several deck crashes. Ultimately Sydney sailed for Korea, with HMAS Tobruk in company, on 31 August 1951. ${ }^{9}$

En route to Korea, preparations continued for the forthcoming operations. This included rehearsal of bombardment spotting procedures, lectures on escape and evasion, planning conferences and small arms practice. Additionally, a number of officers had gone ahead of the ship to observe $\mathrm{RN}$ flying operations in Korea. ${ }^{10}$

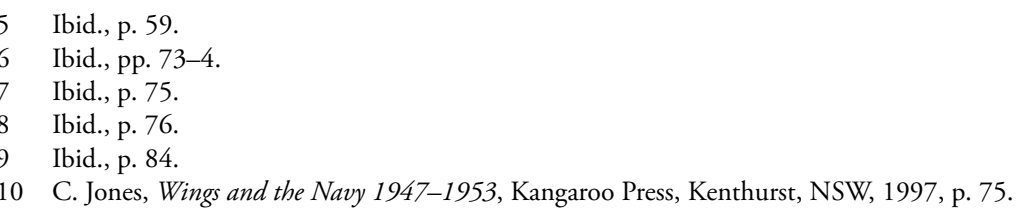


In fact, Australia experienced a major problem in responding credibly to the initial calls for military assistance at the outbreak of war, as other chapters illustrate. There were severe shortages of defence personnel, money was scarce, and the army had fewer than a thousand infantrymen in the regular force-and most of them were in the British Commonwealth Occupation Force (BCOF) in Japan, from which Australia wanted to withdraw anyway. ${ }^{11}$ Additionally, No. 77 Squadron, RAAF, was in Japan and HMAS Shoalhaven was in Japanese waters.

Neither the services nor the Australian prime minister wanted to become involved in Korea. Provision of forces to Malaya had been a consideration in May, and Britain was urging Australia to commit ground and air forces to the Middle East, which was seen as a higher priority in the event of any Soviet attack. ${ }^{12}$ Yet General MacArthur had indicated that he wanted both No. 77 Squadron and the 3rd Battalion of the Royal Australian Regiment (3RAR), the army unit based in Japan. As Robert O'Neill noted in Chapter 1, the Minister for External Affairs, Percy Spender, was keen for Australia to become involved, as he had in mind a future security pact with the United States. Eventually No. 77 Squadron was committed on 30 June and 3RAR on 26 July.

On the naval front, the United States Navy (USN) was not well placed to respond at the beginning of the war. It only had a few ships in Japanese waters, but most of the Seventh Fleet, itself by no means a powerful force then, was in or around the Philippines. On the other hand, the RN was much better placed. A major portion of the Far East Fleet, 22 ships, including a light fleet carrier, was in Japanese waters, escaping the heat of Hong Kong and Singapore. ${ }^{13}$ This force was placed under MacArthur's control.

For the RAN, HMAS Shoalhaven was to be relieved by HMAS Bataan, but both ships remained in theatre initially. They were joined by Canadian and New Zealand units, and all of them operated within the RN force. This British Commonwealth Naval Force formed the West Coast Support

\footnotetext{
11 Ibid., pp. 31-2.

12 Ibid., pp. 38, 41

13 R. O'Neill, Australia in the Korean War 1950-1953, vol. 2: Combat Operations, AWM \& AGPS, Canberra, 1985, p. 416.
} 
Group (Task Group 96.8), while the USN made up the East Coast Support Group (Task Group 96.5), and the Seventh Fleet's carrier force (Task Force 77) operated wherever it was needed. ${ }^{14}$

Shoalhaven was assigned to escort duties between Sasebo and Pusan at first and was relieved by HMAS Warramunga on 31 August 1950. The RAN had consistent problems in replacing ships in Korea, because of shortages of suitable ships and of people. ${ }^{15}$ Other tasking for the surface forces included support for amphibious operations and shore bombardment, often in the face of a significant mine threat, and sometimes with the fear (ultimately unrealised) of a Soviet submarine threat.

From the outset of the war, carriers were in heavy demand, not least because the United States Air Force (USAF) aircraft were in short supply and because North Atlantic Treaty Organization (NATO) and domestic US demands limited the availability of reinforcements. Other factors making carriers attractive were the lack of suitable operating airfields in Korea and the limited time over target for tactical aircraft operating from Japan. ${ }^{16}$

Normally TF77 operated in the open Sea of Japan off the east coast of Korea. The British light fleet carrier force (TE [Task Element] 95.11) normally operated in the more restricted waters off the west coast. Their contribution in aircraft numbers was not great, but it did permit the maintenance of a continuous air offensive off both coasts. After December 1950, a USN light fleet carrier also joined the west coast operation, thereby allowing each of the RN and USN carriers to rotate on station about every 10 days.

In the first year of the war, UN air and sea power prevented almost all enemy movement at sea and fought off the first MiG-15 challenge. With general control of the air, UN forces limited North Korean movements to the night hours. ${ }^{17}$ Generally, the carriers were not attacked, but there was constant anti-submarine screening by escorts.

14 Ibid., pp. 417, 461.

15 Ibid., p. 425.

16 Ibid., p. 464.

17 Ibid., p. 465. 


\section{HMAS Sydney in Korea}

\section{The aircraft}

HMAS Sydney, like the RN carriers, operated a mix of Fairey Firefly and Hawker Sea Fury aircraft. The Firefly was a single-engine, two-seat anti-submarine reconnaissance and strike aircraft, also in widespread $\mathrm{RN}$ service. It had a maximum speed of more than 350 miles per hour (560 kilometres per hour) and an endurance of more than six hours. Weapons included four 20-millimetre cannon and two bombs of up to 1,000 pounds ( 450 kilograms) each. ${ }^{18}$ The RAN had both Mark 5 and Mark 6 aircraft, and because only the Mark 5 had the cannon armament, the RAN took 12 of those aircraft to Korea with No. 817 Squadron, where they also carried two 500-pound bombs for strike missions. ${ }^{19}$ For ASW (anti-submarine warfare) missions, depth charges were substituted for the bombs.

The Sea Fury was a single-engine and single-seat fighter bomber, the last piston-engine fighter to serve with the RN Fleet Air Arm and the only one to serve with the RAN. Its top speed was more than 450 miles per hour (720 kilometres per hour), and it had a range of up to 1,000 nautical miles (1,850 kilometres) with two drop tanks. Armament consisted of four wing-mounted 20-millimetre cannon, and it could carry a mix of either eight 60-pound (27-kilogram) rockets or two 1,000-pound bombs. In Korea, the Furys usually flew with eight rockets and two drop tanks, and had about 125 rounds per gun. ${ }^{20}$ The Sea Fury served with No. 805 and No. 808 Squadrons in Korea.

During operations in Korea, HMAS Sydney also embarked, for the first time, a Sikorsky S51 Dragonfly helicopter. With a crew of two, the Dragonfly had a maximum speed of 95 miles per hour $(150$ kilometres per hour) and a range of 300 nautical miles (550 kilometres). This helicopter was used for search and rescue, for plane-guard duties and inevitably for mail runs. At first the helicopter came from HMS Glory, but for most of the deployment it was provided by the USN. Colloquially it came to be

18 O. Thetford, British Naval Aircraft Since 1912, 6th rev. edn, Naval Institute Press, Annapolis, MD, 1991, pp. 185-6.

19 S. Wilson, Sea Fury, Firefly and Sea Venom in Australian Service, Aerospace Publications, Weston Creek, ACT, 1993, p. 81.

20 Jones, Wings and the Navy, p. 86. 
known as 'Uncle Peter' because of its identification letters. The Dragonfly performed sterling service for Sydney's aircrew during their Korean War deployment.

\section{The ship}

Under the command of Captain D.H. Harries and with Commander V.A.T. Smith as executive officer, Sydney's ship's company worked hard and kept the ship in as good a state as was possible under the prevailing conditions. Sydney did not operate as a flagship, although the Flag Officer Commanding the Australian Fleet, Rear Admiral J.W.M. Eaton, did spend three days in the ship in January 1952. Rear Admiral A.K. ScottMoncrieff, RN (Commander West Coast Blockade Force), also spent time in the ship on occasion. Morale for the most part was very good, although behaviour ashore was not always what was expected. Leave-breaking was a problem, and relations with the ships' companies of other UN force ships were also strained at times. ${ }^{21}$

HMAS Sydney had a single hydraulic catapult, and although free take-offs had often been used before the Korean War, the catapult was invariably used in wartime operations, not least because of the higher take-off weights at which aircraft were operating. The catapult proved to be reliable, with the only failure occurring on 1 January 1952 . Even then, 51 sorties were flown that day after the catapult was repaired. ${ }^{22}$ The average time between launches was 42 seconds, although lower times were recorded. This was a level of flight deck performance that the $\mathrm{RN}$ carriers found difficult to emulate. ${ }^{23}$

With a straight deck, Sydney was more prone to deck landing accidents than the later angled-deck carriers. Nevertheless, her record during the Korean deployment was very good. During the patrol that ended on 13 November 1952, there was only one deck landing accident in more than 400 landings. The fact that no night flying was conducted undoubtedly contributed to the good figures. Pilots averaged one and a half sorties each day in the war zone; but taking into account that not every pilot was always available to fly, most pilots flew two sorties on the days they were available.

21 O’Neill, Combat Operations, p. 486.

22 Ibid., p. 480.

23 Ibid., p. 477. 
With three squadrons totalling 38 aircraft embarked, Sydney's flight deck and hangars were always crowded. Flight deck operations, never to be taken lightly, were invariably made more complex by the need to have 20 of the aircraft always parked on deck. These aircraft were manned and started for every flying event, so that any unserviceable aircraft could be replaced immediately. ${ }^{24}$ After every recovery, unserviceable aircraft were parked forward or taken below for maintenance, while the serviceable ones were taken aft for fuelling and arming. At the end of every flying day, all deck-parked aircraft had to be heavily lashed in case of inclement weather. The handlers, armourers and maintainers worked hard under often difficult conditions. Aircraft maintenance was a never-ending task. On average, 38 per cent of aircraft returned unserviceable-although the figure varied from 29 up to 66 per cent. ${ }^{25}$ All flak damage was repaired overnight.

\section{Air operations in Korea}

Sydney operated mainly in the Yellow Sea and alternated on station with the USS Rendova and USS Badoeng Strait. At that time Operation Strangle was underway. This involved the UN Command (UNC) air forces in interdicting the removal northwards of large North Korean supply dumps and the movement south of combat supplies by the North Koreans. The latter interdiction task proved more difficult because of the North Korean capacity to repair damaged supply routes. ${ }^{26}$ The carrier operating cycle was nominally nine days on patrol and nine days for return to Sasebo and replenishment there. Frequently, however, one of the on-station days was taken up with replenishment at sea, which provided a welcome break for aircrew. The missions flown by the air group were mainly strike, armed reconnaissance, close air support, naval gunfire support spotting, combat air patrol and ASW. Some time was also spent in convoy escort. ${ }^{27}$

24 Ibid., p. 471.

25 Ibid., p. 485.

26 Ibid., p. 350.

27 Major M.B. Simkin, 'HMAS Sydney in Korean Waters', Report by the Carrier Borne Ground Liaison Officer, held by Sea Power Centre-Australia, undated, pp. 1-3. 


\section{Strike operations}

Strike operations were a major component of Sydney's contribution to the war. Target location proved to be difficult, especially at first, because of excellent camouflage by the North Koreans. As the operation continued, the most reliable targeting information was normally photographic or visual reconnaissance provided by Sydney's own aircraft. ${ }^{28}$ Targets varied a great deal and included North Korean artillery positions, coastal shipping (including junks), troop concentrations, road and railway bridges, railway tunnels, buildings and supply vehicles, including ox carts.

A lot of effort went into determining the best method for the Fireflys to bring down bridges - for which direct hits were necessary. Divebombing was tried at first, diving from 8,000 feet and releasing at 3,000 feet. Ultimately they settled on 10-degree dive-bombing at low altitude along the length of the bridges, in flights of four aircraft. ${ }^{29}$ This was the typical ASW depth-charging profile. ${ }^{30}$ With experience, a flight of four Fireflys proved able to bring down three bridges in one sortie. But, however satisfying dropping bridges was to the aircrew, the North Koreans managed to repair them quickly in most cases. This led to the following assessment by the Carrier Borne Army Liaison Officer (CBALO): 'It is of interest to note that the hard night-working Communists have already repaired the large hole we knocked in the rail bridge only three days ago. The Australian Country Roads Boards could well do with a few of these gentlemen!' ${ }^{31}$

North Korean gunners certainly enjoyed some success against RAN aircraft. Aircraft were hit by flak 99 times and nine aircraft were shot down — seven of them Sea Furies. ${ }^{32}$ The gunners did not use tracer and did react to changing aircraft operating patterns, but for the most part aircraft were shot at only after they had passed over enemy positions. The flak could be astonishingly good, and at times equally bad. On the other hand, the aircrew were extremely keen to press home attacks, and some

28 Jones, Wings and the Navy, p. 89.

29 Ibid., p. 86.

30 F. Lane, 'Naval aviation in the Korean War', Naval Officers Club Newsletter, No. 60, 1 March 2005, p. 18.

3172 CBAL Section, HMAS SYDNEY, War diary—Korean operations, 21 October 1951.

32 O'Neill, Combat Operations, p. 483. The actual number of aircraft lost varies among sources. Taking account of enemy action and all other causes, 13 aircraft appear to have been lost: nine Sea Furys and four Fireflys. 
consideration was given to setting minimum altitudes (below which it was not permitted to fly) and a maximum number of attack runs. This became more of an issue as anti-aircraft fire increased. ${ }^{33}$

\section{Other operations}

During the voyage to Korea, much time was spent in practising naval gunfire support spotting techniques. The time was well spent, as the subsequent results while in Korea were impressive. The aircrews especially enjoyed working with the big gun ships, such as USS New Jersey, because of the much greater accuracy of their guns. ${ }^{34}$

Twenty per cent of sorties-about 10 each day-were flown as combat air patrol over Sydney, because of the proximity of North Korean airfields. The extent of the self-defence effort led to a view that the carriers would be more effective if operating in pairs or in larger groups. ${ }^{35}$ No Sydney combat air patrol ever intercepted an enemy aircraft. ${ }^{36}$

Normally, just one Firefly was assigned to ASW, because of the low level of threat. The same aircraft was also often used for surface contact identification and for search and rescue assistance. ${ }^{37}$

\section{Sydney's patrols}

Sydney's first patrol began on 5 October 1951, as part of the operation to push the front back from the Han River and the approaches to Seoul. ${ }^{38}$ She flew 47 sorties on each of the first two days, a rate that was considered quite high for a ship new to the theatre. During this first patrol, Sydney was ordered to join a special force under Rear Admiral Scott-Moncrieff on the east coast. She subsequently flew strikes against positions south-east of Wonsan, but without clear details of the purpose of the overall mission. Later, the operation proved to have been a demonstration for the benefit of Admiral Sir Guy Russell, RN, visiting from Hong Kong. ${ }^{39}$

33 Ibid., p. 484

34 Australian Naval Aviation Museum, Flying Stations, p. 89.

35 O'Neill, Combat Operations, p. 472.

36 Lane, 'Naval aviation in the Korean War', p. 16.

37 O’Neill, Combat Operations, p. 472.

38 Jones, Wings and the Navy, p. 77.

39 O'Neill, Combat Operations, p. 470. 
Captain Harries set a demanding daily sortie rate, but one that was achievable and sustainable: 54 sorties, spread over five events or waves. The shortness of the winter days and the distance to targets made any more than five events difficult to achieve. This followed some quite exceptional flying performances, such as that on 11 October, when 89 sorties were flown. At one time, late in the day, 31 aircraft were airborne at the same time. ${ }^{40}$ This sortie rate was a record for the light fleet carriers, but was subsequently bettered by HMS Glory.

The second patrol, which began on 18 October, was quite eventful. It involved attacks against railway bridges and tunnels as part of a major interdiction campaign, and strikes against enemy troops and coastal shipping. It was during this patrol that the first close air support sorties were flown, for the British Commonwealth Division on 21 October. This sometimes included providing cover for South Korean troops and irregular forces, and was most popular when ordered in support of Australian troops.

Although the pilots really enjoyed this work, ${ }^{41}$ it was not without hazard; on 25 and 26 October, for example, three aircraft were shot down. Lieutenant Col Wheatley's Fury ditched off Chinnampo; Lieutenant Commander J.C. Appleby's Fury was badly damaged by flak but he managed to get it to Kimpo. Then Sub Lieutenant Noel Knappstein's Fury crash landed on mud flats in the Han River estuary. ${ }^{42}$ The pilot was rescued by HMS Amethyst, but before being picked up he had removed some salvageable equipment from the aircraft. Then, showing commendable enterprise, he sold the remains of the aircraft to some local Koreans. It was a very satisfied Sub Lieutenant Knappstein who returned on board Sydney with a thick wad of Korean notes. The supply officer duly changed them into coin of the realm and presented him with ... one shilling and ninepence. ${ }^{43}$

On 18 November Sydney left Sasebo in company with HMS Belfast, HMAS Tobruk and several USN ships for Operation Athenaeum. This was to be a major bombardment of Hungnam on the east coast. In two days Sydney launched 113 sorties, of which 75 were against Hungnam coastal batteries and 38 were defensive combat air patrols for the ships.

40 Jones, Wings and the Navy, p. 78. Reference to the 72 CBAL Debriefing Reports shows that in fact 93 aircraft sorties were flown on that day.

4172 CBAL Section, HMAS SYDNEY, War Diary-Korean Operations, 31 October 1951.

42 O'Neill, Combat Operations, p. 474.

43 Jones, Wings and the Navy, p. 84. 
The operation was not notably successful, and Sydney returned to the west coast for operations in poor weather. Returning to Kure at the end of this patrol on 30 November, Sydney's air group had flown 966 offensive and 360 defensive sorties; 43 aircraft had been hit, and four had been lost. ${ }^{44}$

In mid-December, HMAS Sydney became involved in convoy escort, after the UNC decided to exchange the operational tasking of the US Fifth Air Force with that of the west coast carrier force. Convoy escort was a task the aircrew found intensely frustrating, mainly because it almost invariably proved to be boring. During this particular patrol, before the change to convoy protection, much more flak damage was taken, with 25 aircraft damaged and five destroyed between 6 and 18 December. This was more than half the total number of aircraft lost to enemy action in the entire deployment.

After Christmas in Kure, Sydney began her sixth patrol on 28 December, this time conducting more airstrikes in the area of Cho Do and Sok To. Targets included North Korean artillery and junk concentrations. Sorties were also flown in support of South Korean troops and irregular forces. ${ }^{45}$ On 4 January 1952, Rear Admiral Scott-Moncrieff personally briefed attacks on gun positions along the Yesong River, close to Panmunjom. Lieutenant Peter Goldrick was wounded during this operation but managed to bring his aircraft back and land safely on Sydney. Navy Office was informed of the incident, and in its reply to the ship displayed the kind of humour that we have all come to associate so readily with head office. Navy Office directed that Lieutenant Goldrick's flying pay was to cease from the moment he had been wounded, as he was then temporarily unfit to fly and might never fly again.

The seventh and final patrol began on 16 January. Bad weather and poor coordination between the blockading force and convoys affected the flying rate. Nevertheless, North Korean gunners still managed to damage 10 aircraft. During this patrol, strike targets were switched from rail infrastructure to water towers, on the basis that water towers would take longer to repair. ${ }^{46}$ No flying was possible on the final day of operations, 25 January. Cold and the overnight snow had rendered all deck-parked aircraft unserviceable. The five forward-most Furys were almost totally covered in frozen salt water. 
All in all, during the deployment Sydney's Air Group flew 743 Firefly sorties and 1,623 Sea Fury sorties. Nine aircraft were destroyed and a further 90 aircraft were damaged by flak. ${ }^{47}$

\section{The Carrier Borne Army Liaison Section}

One of the most important behind-the-scenes organisations in Sydney was the combined Carrier Borne Army Liaison (CBAL) Section, which was manned by officers and men from 71 and 72 Sections. It comprised two majors, one of whom, M.B. Simkin, had flown to Korea ahead of the ship, two warrant officers class 2 and two corporals. En route to Korea, as well as conducting bombardment spotting practice, the CBAL Section also provided briefings on escape and evasion and Owen gun practice for Firefly crews. ${ }^{48}$

Once on operations, each of the majors briefed and debriefed alternate flying events. They also undertook target assessment, and on each evening proposed a target list for the following day's operations to the commander (air), the air group commander and the operations officer. The section also kept up-to-date situation and flak maps and maintained target dossiers and files of briefing photographs. A store of more than 200,000 maps and charts was also maintained by the section. ${ }^{49}$ Other specific tasks for which the CBAL Section was responsible included the provision of army advice to the captain, through the commander (air); the provision of all intelligence information to aircrew; and the collection and assessment of all flak information.

Busy as they undoubtedly were, the army personnel were not entirely oblivious to their surroundings. They developed a comprehensive handover process for replacement personnel, which included a set of 'How to survive the Navy' instructions: (1) Never sign for anything. The Naval Supply Branch never forgets; (2) enjoy your food, eat ashore; (3) treat all parts of the ship as though they have been freshly paintedthey probably have been; (4) if you should require a drink after the bar shuts, follow the trail of Air Group officers to cabin G67.

47 Jones, Wings and the Navy, p. 90.

4872 CBAL Section, HMAS SYDNEY, War Diary-Korean operations, 5 September 1951 and 3-4 October 1951.

49 Ibid., 5 October 1951. 


\section{Other challenges}

Quite apart from the dangers associated with carrier aviation and lowlevel flying in the war zone, there were several other matters that made life difficult from time to time. Of these, weather was probably the most significant and most frequent.

Sydney's first real taste of what was in store came on 14 October, when all Commonwealth ships in Sasebo were ordered to sail in order to ride out the approaching Typhoon Ruth. Some in HMAS Sydney wanted to remain in harbour, noting that Sasebo was surrounded by mountains 2,000 feet high. Nevertheless, she did sail and met the full force of the storm with 18 aircraft lashed down on the flight deck. Chocks and fastening lugs were torn away from aircraft, and the heavy movement of the ship collapsed some undercarriage legs. Minor electrical fires broke out in the ship as seawater shorted out ventilator fan motors. ${ }^{50}$ Four aircraft broke free and were washed overboard, and many others were damaged. ${ }^{51}$ The ship itself survived pretty well.

As the winter progressed, intense cold, low cloud and snow also caused problems. Snow tended to settle only on the forward and aft sections of the flight deck, as the relative warmth from the hangars melted it elsewhere. Aircraft often had to be thawed below decks, and engine oil in deck-parked aircraft often had to be diluted at night so that engines could be started in the morning. Propellers and wing leading edges were coated with an anti-icing paste that made the deck slippery. Cold also damaged propeller seals and coolant hoses. ${ }^{52}$

These conditions of course made working on aircraft on the flight deck extremely difficult. Often, fine work requiring the removal of gloves could not be done for more than five minutes at a time. For the aircrew, immersion suits were always needed, and map reading was a constant challenge over snow-covered country. There were also days when the weather was simply too bad to allow flying-low cloud, wind and snow being the usual culprits.

50 O’Neill, Combat Operations, p. 472.

51 Ibid., p. 473. Fred Lane disputes this figure, claiming that only one Firefly was lost overboard, together with a motor boat and a forklift. See Lane, 'Naval aviation in the Korean War', p. 18.

52 O’Neill, Combat Operations, p. 473. 
Although it did not necessarily affect individual aircrew, command and control was a periodic headache for the command. Much of the problem was cultural, with the RAN and RN ships generally unhappy with the degree of prescription and detail contained in USN operation orders. There was also an underlying friction between Rear Admiral Scott-Moncrieff and his USN superiors, Vice Admiral Dyer or Vice Admiral Joy, and which preceded Sydney's arrival in Korea. More often than not the cause of the friction was an unfortunate level of mutual misunderstanding. ScottMoncrieff was sceptical of the value of some US-proposed operations when weighed against the risk to his ships. He was also mindful that the smaller navies, like those of Australia and Canada, could ill afford to lose ships in such operations. ${ }^{53}$ The USN hierarchy, in contrast, felt that the $\mathrm{RN}$ had a half-hearted approach to the war and was prepared to allow the USN to take the risks so that British forces could be conserved.

During Sydney's time, the most significant such issues arose with the UNC's decision to institute a temporary exchange of duties between the US Fifth Air Force and the west coast carrier force. Admiral Joy had argued for the switch on the ground that it would be sensible for the naval aircraft to take over the convoy escort role between Japan and Korea if the Fifth Air Force took over the strike and ground support roles of the carrier force. ${ }^{54}$ Scott-Moncrieff disputed the move because of the familiarity his aircrews now had with the terrain of north-west Korea and because of the monotony associated with the convoy protection task. Through all of this, Harries was in full agreement with Scott-Moncrieff.55

The rescue of downed aircrew was another major challenge associated with operations in Korea. Robert O'Neill noted that the air war virtually ceased until downed aircrew were located and, where possible, rescued. ${ }^{56}$ Sydney made her own unique contribution. The first innovation was to provide pilots with fluorescent panels, two feet (60 centimetres) square, coloured red and yellow. They could be laid out on the ground to indicate the condition of aircrew, the location of enemy troops and the intentions of the aircrew. ${ }^{57}$ The second element was a message bag that could be dropped to downed aircrew. Both innovations were taken up by other air forces in Korea.

53 Ibid., p. 453.

54 Ibid., pp. 478-9.

55 Ibid., p. 479.

56 Ibid., p. 486.

5772 CBAL Section, HMAS Sydney, War Diary—Korean Operations, 29 October 1951. 


\section{Effectiveness and achievements}

During her Korean War deployment, Sydney spent 122 days in Korean and Japanese waters. Of these, 42.8 days were spent on flying operations, 11.7 days were lost to poor weather, 29.5 days were spent on passage or in replenishment and 38 days were spent in harbour. ${ }^{58}$

Financially, it was a costly deployment, but carrier air power was a necessary counter to North Korea's land force predominance and a lack of suitable air bases in Korea. Fortunately, Sydney lost only three aircrew killed. The three, all Sea Fury pilots, were Lieutenant Kenneth Clarkson and Sub Lieutenants Dick Sinclair and Ron Coleman. Looked at in terms of the damage caused to North Korean infrastructure, logistics support and the number of troops killed, the result is mixed. The official figures (although sources do vary a little) are: 3,000 enemy troop casualties, 66 bridges destroyed-many of them more than once, seven tunnels damaged, 495 junks and sampans sunk or damaged, and 15 artillery pieces damaged or destroyed.

As Chapter 6 attests, battle damage assessment was quite difficult, and Sydney's aircrew and the CBALO's staff took a notably conservative view of their achievements. For example, unless bodies could be counted, rockets had to be seen to hit known numbers of troops before kills were accepted. ${ }^{59}$ That the approach was conservative was confirmed by 'Leopard', the US leader of an irregular ground force group. His assessments on the ground indicated that RAN aircrew were underestimating their impact. That they were doing so had important ramifications in that it contributed to the US dissatisfaction with the performance of the Commonwealth forces. On the other hand, RAN aircrew were said to have been bemused by the American penchant for figures of often doubtful reliability.

Issues such as these might well have contributed to a degree of frustration that had emerged among the aircrew by the end of the deployment. A much more significant cause, however, might have been the inability to shut down the North Korean supply lines completely. This inability simply reflected the realities of the limits of air interdiction, seen also in Vietnam in the $1960 \mathrm{~s} .{ }^{60}$ Some of the aircrew involved bemoaned what seemed to

58 O’Neill, Combat Operations, p. 485.

59 Australian Naval Aviation Museum, Flying Stations, p. 86.

60 Jones, Wings and the Navy, p. 89. 
be the exchange of North Korean oxcarts and peasants for UN aircraft and aircrew. The significance of this criticism is evident in the decision by US and RN authorities to switch from tactical targets to strategic ones, such as petrochemical installations and powerhouses. Only then, after Sydney had departed, did the North Koreans begin to show flexibility in the armistice talks. ${ }^{61}$

Yet, although there might have been some disappointment at their inability to close down North Korean supply lines, the RAN aviators should have been satisfied with their efforts. They created significant problems for North Korean logistic support, and ensured that most, if not all, such movements took place only at night. They also provided ground troops with consistently accurate close support. Perhaps unknown to them at the time, Sydney and her air group at the political level enabled Australia to avoid having to commit additional ground forces to the conflict. ${ }^{62}$ For their efforts they were awarded three Distinguished Service Crosses and one Bar, one Distinguished Service Medal and two US Legion of Merit awards. As the CBALO, Major Simkin, noted in his official diary, 'Australian Naval Aviation can be justly proud of its first major war effort'. ${ }^{63}$

\section{The aftermath}

The Korean War heralded a new Australian naval construction program, announced in February 1952. It was to include six River Class frigates, one replenishment ship, three boom defence ships and four coastal minesweepers. It was also to include modernisation of the cruiser HMAS Hobart, the three Tribal Class destroyers, and conversion of the Q Class destroyers to fast anti-submarine warfare frigates. ${ }^{64}$

The Fleet Air Arm was not forgotten in the program. HMS Vengeance was offered on loan to the RAN while HMAS Melbourne was being modernised. Additionally, Sea Venom and Gannet aircraft were ordered in 1951 and 1952, respectively. Schofield's airfield also became HMAS Nirimba on 1 April 1953, with two reserve air squadrons, a repair base and the captain (air). ${ }^{65}$

61 Australian Naval Aviation Museum, Flying Stations, p. 84.

62 O'Neill, Combat Operations, p. 486.

63 Simkin, 'HMAS Sydney in Korean Waters'.

64 Jones, Wings and the Navy, p. 95.

65 Ibid., pp. 101-2. 
The personnel element of this program was planned to see the navy grow from 10,252 Permanent Naval Forces (PNF) and 4,943 citizen force members in 1950 to $17,000 \mathrm{PNF}$ and 10,000 national servicemen. The closest it got to that target was a strength of 14,144 PNF and 7,398 citizen force members in 1953.

Circumstances, however, conspired to curtail the program. Hostilities ceased in Korea in 1953, and the focus of Australian defence efforts changed from the Middle East-a Commonwealth commitment-to South-East Asia. As well, high inflation in 1954 saw the imposition of cuts in the defence program. These resulted in cancellations and delays to building and modernisation activities.

Nevertheless, HMAS Melbourne entered RAN service in 1955, together with her Sea Venom and Gannet aircraft. But Sydney was not modernised and ceased to be a front-line aircraft carrier. Additionally, a mere four years after Melbourne entered service, seven years after Sydney returned from her successful wartime deployment (and a mere 11 years after the Fleet Air Arm was established), the government decided that carrier aviation would have no further place in Australias defence and that the carrier and its aircraft would be paid off in 1963. A reprieve was subsequently granted, but for the carrier and fixed-wing aviation it lasted only until 1982-83.

There is a question as to whether Australia could have done more to ensure the survival and growth of naval aviation. The question is relevant, as the nation recently acquired two large amphibious ships (HMAS Canberra and HMAS Adelaide) with flight decks as big as any ever before in the Australian inventory. Some questions remain about whether Australia will make the most of the aviation potential of these ships. 
This text is taken from In from the Cold: Reflections on Australia's Korean War, edited by John Blaxland, Michael Kelly and Liam Brewin Higgins, published 2020 by ANU Press, The Australian National University, Canberra, Australia. doi.org/10.22459/IFTC.2019.07 